\title{
Ultrastructural study of the host-parasite relationship, including encapsulation, of Buccinum undatum (Gastropoda, Prosobranchia) infected with daughter sporocysts of Zoogonoides viviparus (Trematoda, Zoogonidae)
}

\author{
Marianne Køie \\ Marine Biological Laboratory, DK-3000 Helsinger, Denmark
}

\begin{abstract}
Daughter sporocysts of Zoogonoides viviparus (Olsson 1868) Odhner 1902 (Trematoda, Zoogonidae) occur in the tissue between the tubules of the digestive gland of Buccinum undatum L. (Prosobranchia, Buccinidae). Sporocysts in naturally infected snails were studied by light, transmission and scanning electron microscopy. The external surface of the sporocyst is increased by irregular tegumental projections. Haemocytes adhere to the tegument of young sporocysts. Older sporocysts are surrounded by flattened haemocytes. No injured parasite or host cell membranes were found. The sporocysts and developing cercariae feed upon host haemolymph and disintegrated extracellular material. The body wall of moribund or dead sporocysts may be attacked by phagocytizing haemocytes. Amoebocytic and phagocytic haemocytes take part in the process of encapsulation and destruction of the parasite. A granuloma formation remains after an encapsulated and subsequently completely removed parasite.
\end{abstract}

\section{INTRODUCTION}

The first intermediate host of the digenetic trematode Zoogonoides viviparus (Olsson 1868) Odhner 1902 (Zoogonidae) is the common whelk Buccinum undatum $\mathrm{L}$. The cercariae encyst in ophiuroids, polychaetes and molluscs. The adult is a common flatfish parasite in the northern Atlantic Ocean (Køie 1976).

The present study describes changes in connective tissue of the visceral mass of naturally infected Buccinum undatum caused by daughter sporocysts of Zoogonoides viviparus. The ultrastructure of the cercaria of $Z$. viviparus in $B$. undatum has been described previously (Køie 1971c).

\section{MATERIALS AND METHODS}

Buccinum undatum L. (Prosobranchia, Buccinidae) (shell length 40 to $50 \mathrm{~mm}$ ) were dredged in the North- ern Øresund, Denmark. Pieces not exceeding $1 \mathrm{~mm}^{3}$ of the visceral mass of whelks naturally infected with daughter sporocysts of Zoogonoides viviparus were fixed for 2 to $3 \mathrm{~h}$ in cold glutaraldehyde in $0.1 \mathrm{M}$ cacodylate buffer ( $\mathrm{pH} 7.4$ ), and postfixed for 1 to $1 \frac{1 / 2}{\mathrm{~h}}$ in cold $1 \%$ osmium tetroxide in the same buffer. After dehydration in ethanol, the pieces were embedded in Epon via propylene oxid. Sections of 60 to $80 \mathrm{~nm}$ were stained with uranyl acetate and lead citrate and studied in a Zeiss EM9 electron microscope. Semi-thin $2 \mu \mathrm{m}$ sections of the Epon-embedded material were stained with toluidine blue.

For scanning electron microscopical study, material was fixed as described above, dehydrated through ethanol and benzene, freeze-dried, coated with a thin layer of gold and examined in a Cambridge Stereoscan electron microscope.

Three whole infected Buccinum undatum and pieces $\left(1 \mathrm{~cm}^{3}\right)$ of the visceral mass of 10 whelks with different degrees of infection were fixed in Bouin's fixative, embedded in Tissuemat, serially sectioned at $6 \mu \mathrm{m}$, 

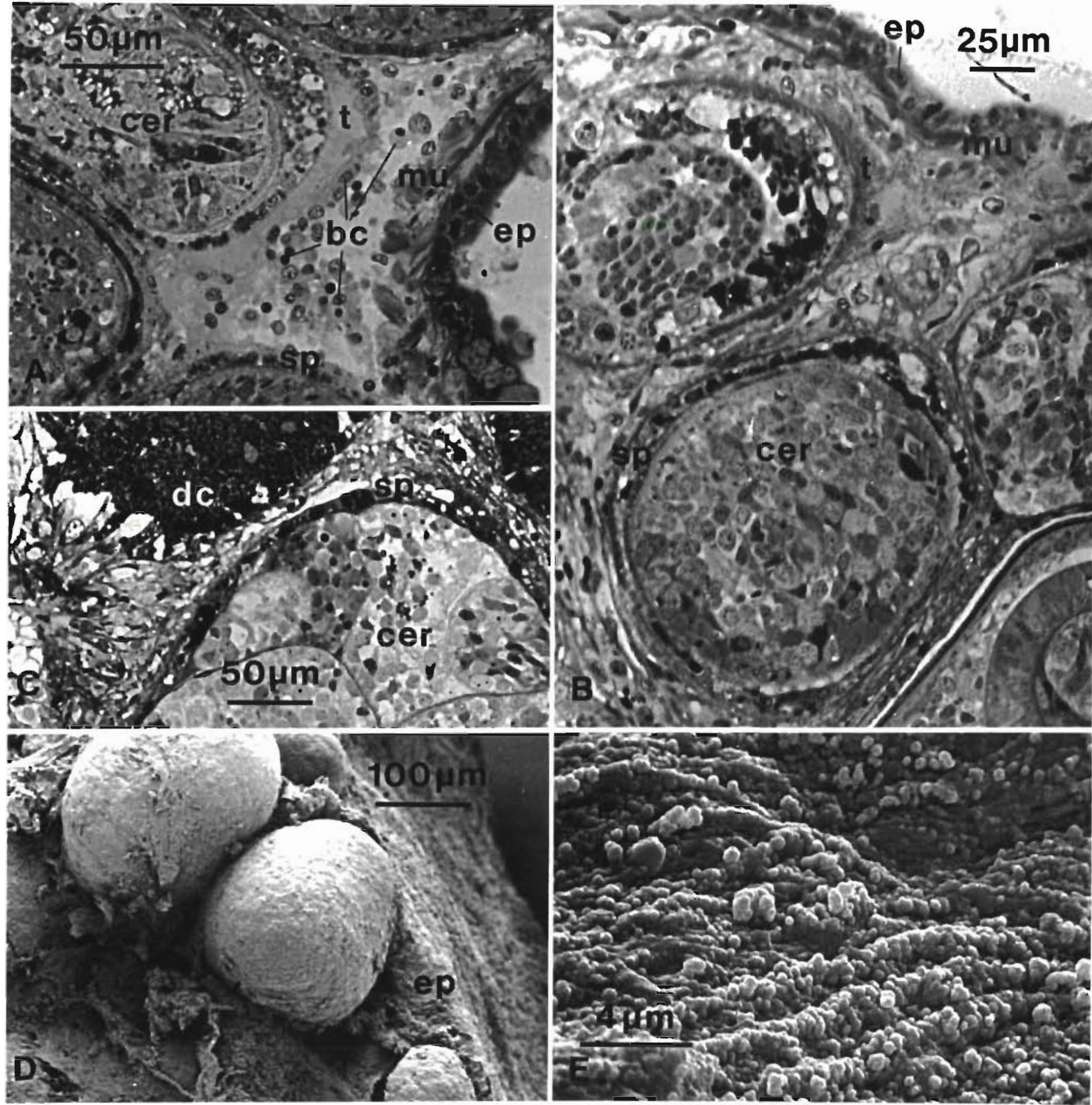

Fig. 1. Buccinum undatum. (A) Section through 4 young daughter sporocysts of Zoogonoides viviparus in the visceral mass Numerous haemocytes are attached to the tegument of the sporocysts. LM, Epon, stained with toluidine blue. (B) An older infection. The area between the sporocysts is occupied by connective tissue. LM, Epon, toluidine blue. (C) A sporocyst and part of 2 digestive gland tubules. The digestive gland cells are filled with large toluidine blue-positive vacuoles. This is a pathological alteration due to the presence of the parasite. LM, Epon, toluidine blue. (D) SEM micrograph showing a broken visceral mass to reveal the sporocysts and connective tissue. (E) SEM micrograph of the external surface of a sporocyst

Abbreviations for figures. bc: haemocyte (blood cell); bl: basal lamina; cer: cercaria(e); dc: cell(s) in digestive gland; el: elongate, electron-dense body in snail cell; ep: epithelium covering the visceral mass; f: extracellular fibres; gl: glycogen particles (?); ger: rough endoplasmic reticulum; ic: intercellular space; l: lipid droplet; ly: lysosome-like vesicle; m: mitochondrion; mb: myelin-like body; mt: microtubule; mu: muscle fibre; $n$ : nucleus; ne: nerve axon; sb: spherical body in tegument and tegumental cell body; sp: sporocyst body wall; sv: spherical vesicle in transformed haemocyte; t: tegument; tp: tegumental 

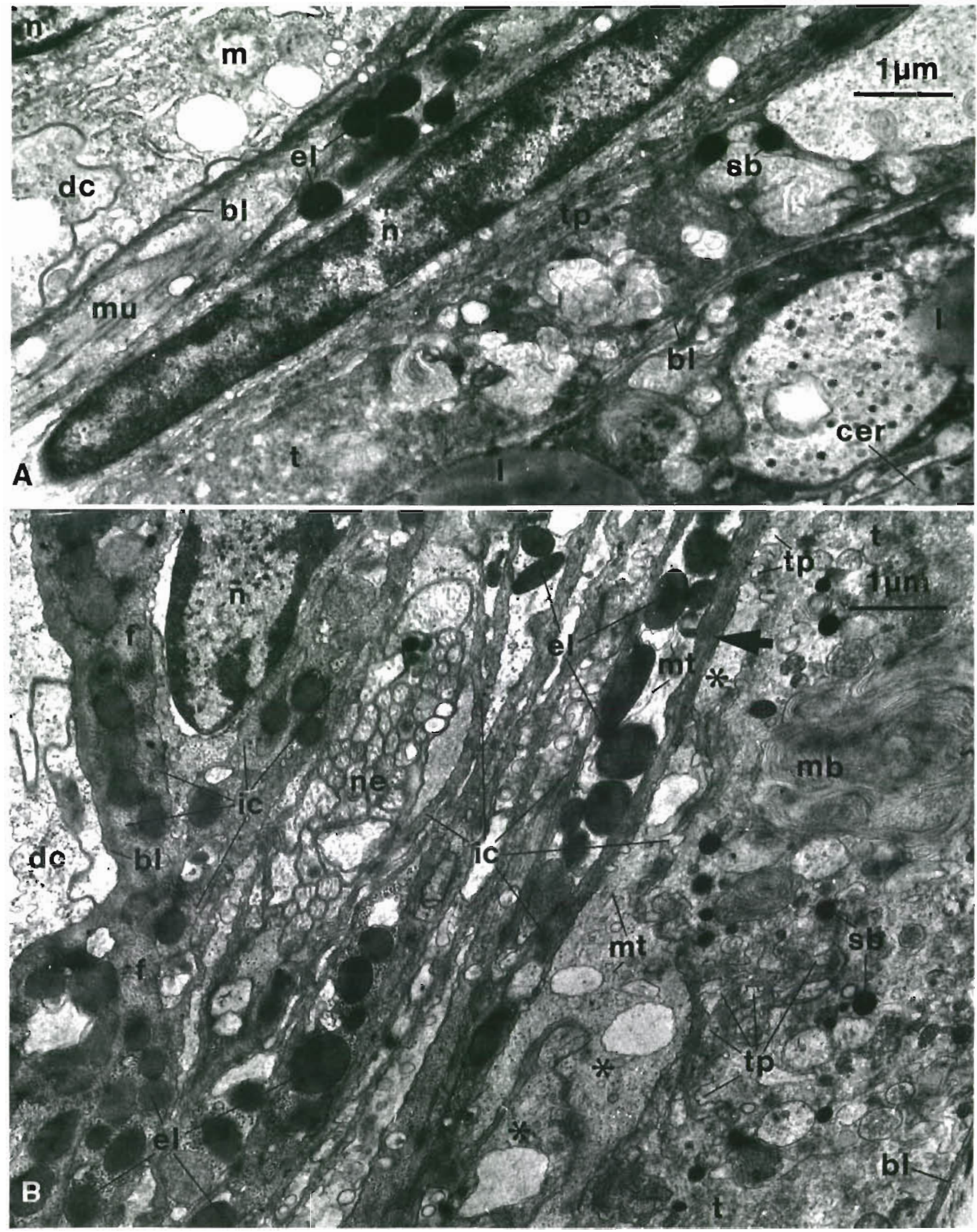

Fig. 2. Buccinum undatum parasitized by Zoogonoides viviparus. (A) TEM micrograph of a sporocyst body wall. A flattened haemocyte with flattened nucleus separates the tegument from the digestive gland cells. (B) TEM micrograph showing the tegument (right) and snail tissue (left). Thin processes of supposed flattened haemocytes (asterisks) separate the tegument from the remaining intertubular tissue. A nerve axon and cell processes containing elongate electron-dense granules are seen. The contents of the electron-dense granules are apparently released into the intercellular space (arrow). A supposed flattened haemocyte is seen at upper left. The intercellular space is densely packed with extracellular fibres. Between the tegumental projections an amorphous material is seen 


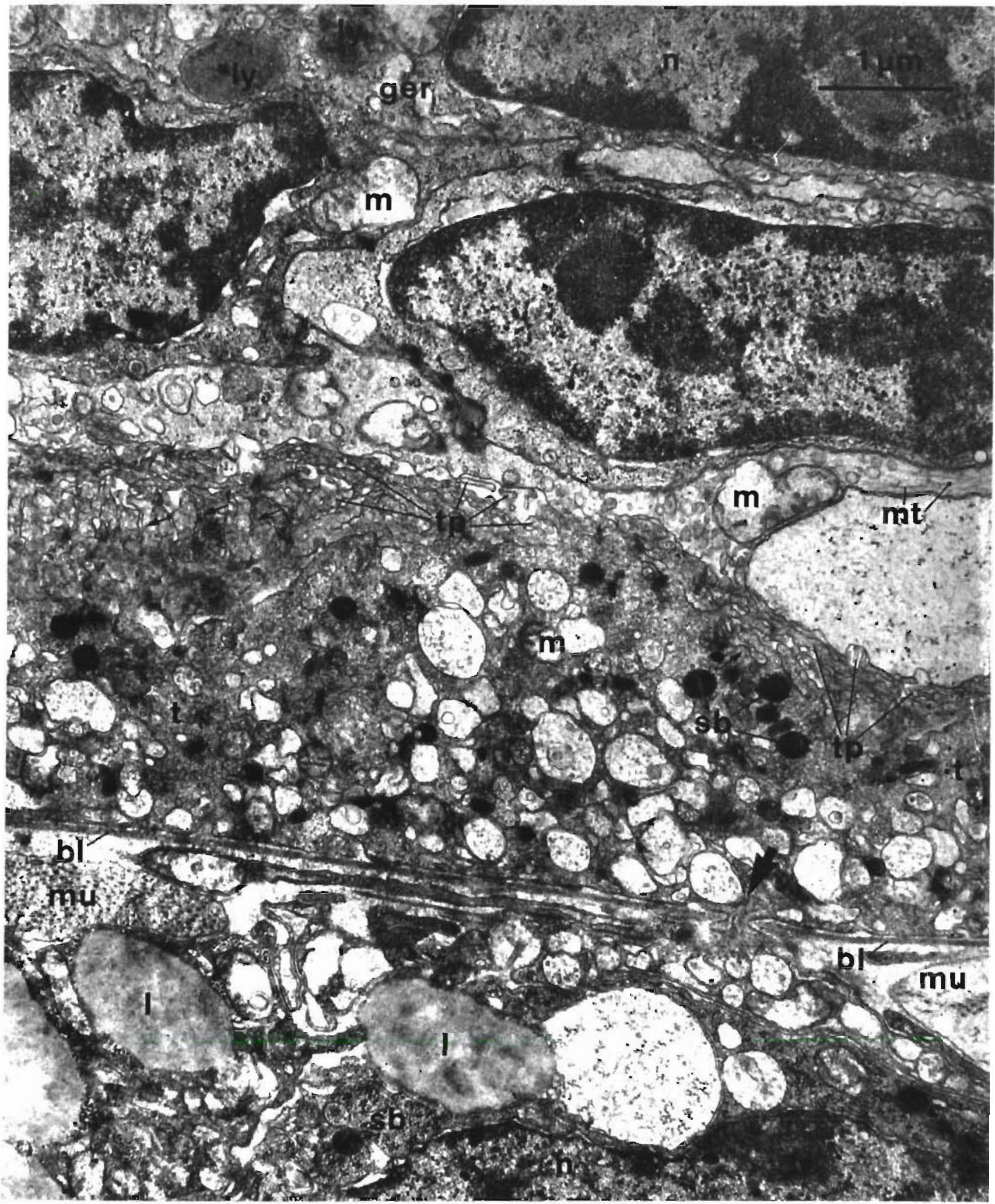

F1g. 3. Buccinum undatum parasitızed by Zoogonordes viviparus. TEM micrograph of flattened haemocytes closely applied to the tegument. Note intact host cell membrane and amorphous matenal between the tegumental projections. Deep channels into the tegument may reveal pinocytotic activity (thun arrows). A cytoplasmic connection between the tegument and a tegumental cell body below the basal lamina is seen (thuck arrow) 
and stained with Ehrlich's hematoxylin-eosin, Heidenhain's azan and toluidine blue.

\section{RESULTS}

\section{Normal host-sporocyst interaction}

Light microscopy

No mother sporocyst was found. The oval daughter sporocysts (Fig. 1) are up to $2 \mathrm{~mm}$ long.

Even in young infections the sporocysts are scattered throughout the visceral mass. Here they occur in the tissue between the tubules of the digestive gland and the gonad. Mature sporocysts first appeared in the gonadal region. The sporocysts replace the gonadal tissue and most of the digestive gland in older infections. The sporocysts are surrounded by intertubular tissue consisting of different types of connective tissue cells, muscle fibres, nerve axons and blood vessels. Haemocytes occur in the vessels and between the intertubular cells.

Haemocytes adhere to the tegument of young sporocysts (Fig. 1A). Older sporocysts are surrounded by compact connective tissue, and most cells close to the tegument have flattened nuclei (Fig. 1B, C). These sporocysts are unable to move in the snail tissue. They produce cercariae which are able to migrate through the surrounding connective tissue (Køie 1971c).

\section{Electron microscopy}

The external surface of the sporocysts is increased by irregular knobs and short ramified projections. The 1 to $4 \mu \mathrm{m}$ thick tegument may have deep fissures, or numerous deep channels (Fig. 2 \& 3). The tegument is rich in vesicles and vacuoles which vary in size and shape and have more or less electron-dense contents. Mitochondria, myelin-like bodies and electron-dense, spherical bodies are common in the tegument. The spherical bodies are formed in the tegumental cell bodies, which occur below the basal lamina and are in connection with the syncytial tegument through thin cytoplasmic bridges (Fig. 3). Poorly developed and sparsely distributed muscle fibres occur below the basal lamina. The subtegumental layer also contains different types of parenchymatous cells, some of which are rich in lipid droplets and glycogen particles (Fig. $2 \mathrm{~A} \& 3)$.

Many sporocysts occur close to tubules of the digestive gland. The tegument of the sporocyst and the basal lamina of the digestive gland are separated by connective tissue cells or muscle fibres (Fig. 2).
The flattened cells which surround the sporocysts contain rough endoplasmic reticulum, microtubules, mitochondria, vesicles and vacuoles which differ in size and shape, lysosome-like vesicles, ribosomes or glycogen particles (Fig. 3). The host cells do not adhere to the sporocysts, and the tegument is therefore clean when the sporocysts are removed from the snail tissue (Fig. 1D, E).

No host cell injury is recognizable (Fig. $2 \& 3$ ). The extracellular fibres close to the tegument are apparently lysed (Fig. 2B).

The haemocytes of infected snails have different shapes and contents (Fig. 4).

\section{Encapsulation}

Light and electron microscopy

About $1 \%$ of the sporocysts are encapsulated by snail cells and more or less degenerated. Encapsulated sporocysts are especially common in the gonadal re-

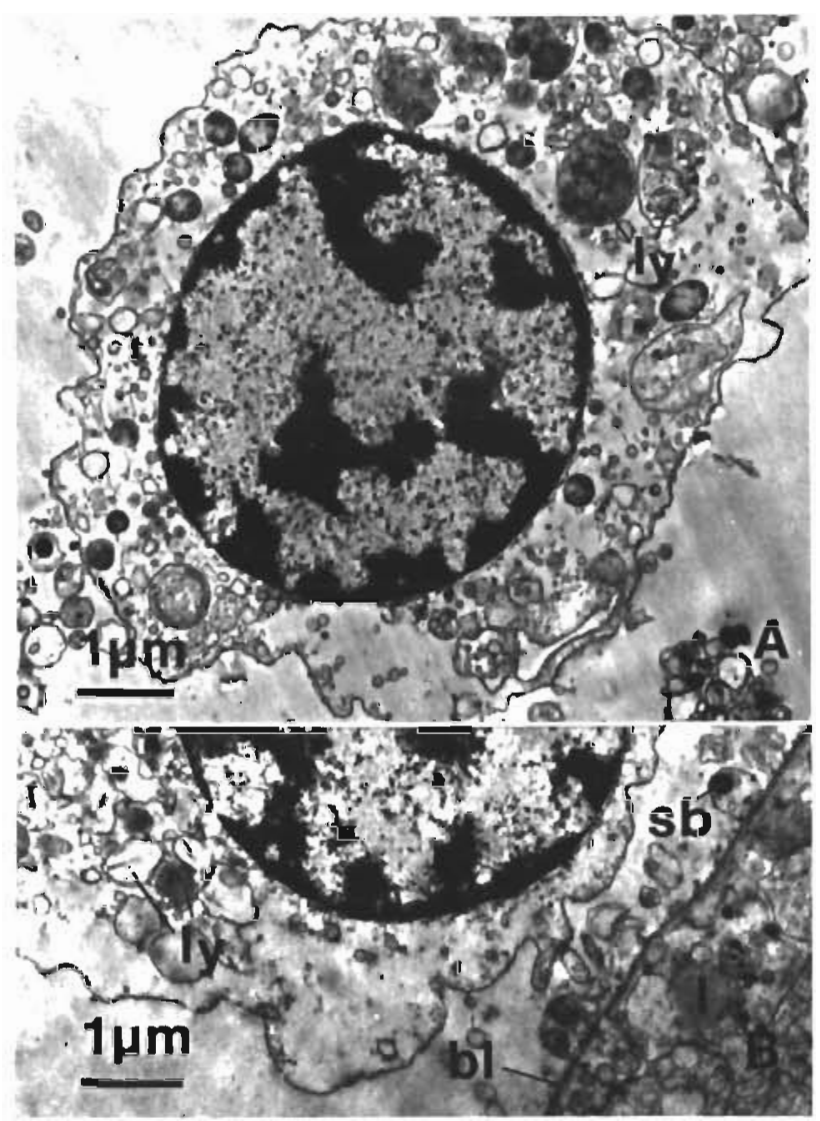

Fig. 4. Buccinum undatum parasitized by Zoogonoides viviparus. (A) TEM micrograph of haemocyte from an infected snail. (B) Haemocyte engaged in active phagocytosis of the tegument 

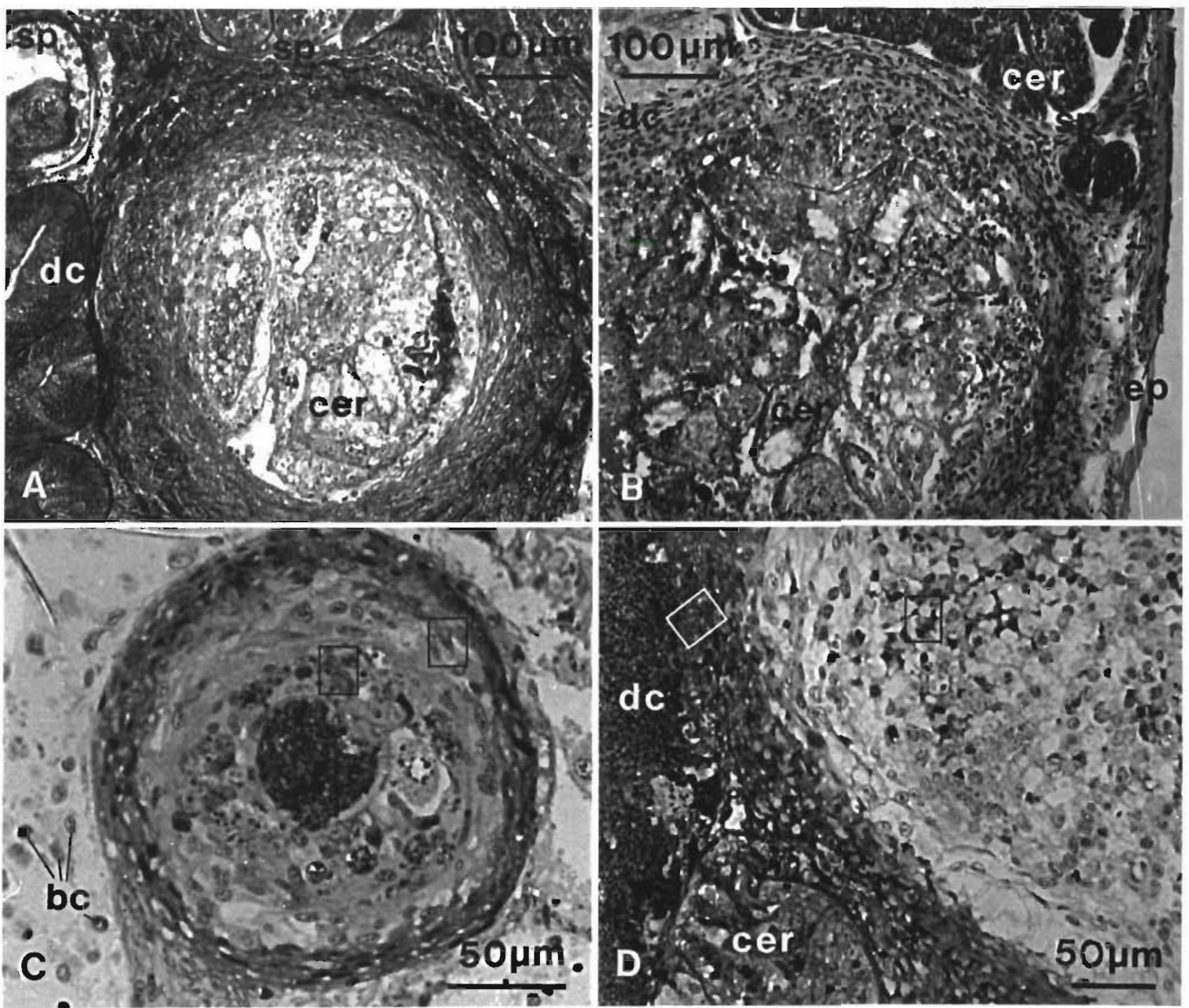

Fig. 5. Buccinum undatum parasitized by Zoogonoides viviparus. (A) An encapsulated sporocyst. The outer part consists of tightly packed, flattened haemocytes. Remains of dead cercariae are seen in the center of the capsule. LM, Tissuemat, Heidenhain's azan. (B) Another encapsulated sporocyst. The central mass is composed of degenerating cercariae and phagocytizing haemocytes. LM, Tissuemat, toluidine blue. (C) A compact capsule with no apparent parasite remains. Residual granules occur in the center. Framed areas correspond to Fig. 6A, B. LM, Epon, toluidine blue. (D) A granuloma formation. Framed areas correspond to Fig. 6C, D. LM, Epon, toluidine blue

gion (Fig. 5A, B). The encapsulation begins with phagocytizing of the tegument by haemocytes (Fig. 4B)

Aggregating haemocytes form a compact capsule around the damaged sporocysts (Fig. 5A, B). The peripheral flattened haemocytes are very similar to the flattened cells which surround living sporocysts. Some cells contain small spherical, lysosome-like vesicles and high concentrations of supposed glycogen particles (Fig. 6A)

The innermost cells of the capsule act as phagocytes. Phagocytosis of parasite tissue is followed by formation of residual bodies of indigestible material in cells in the center of the capsule (Fig. 6B). As some of these cells die a dense core of residual bodies is formed (Fig. $5 \mathrm{C}$ ). It is likely that some of the peripheral cells of the capsule become amoebocytic and migrate to other areas of the snail. The cells containing the residual bodies may migrate from the capsule center to the peripheral layer. However, most cells in the capsule remain and a homogenous tissue replaces the removed parasite (Fig. 5D \& 6C,D). This granuloma formation is composed of large rounded cells containing lysosomelike vesicles and small spherical vesicles. 


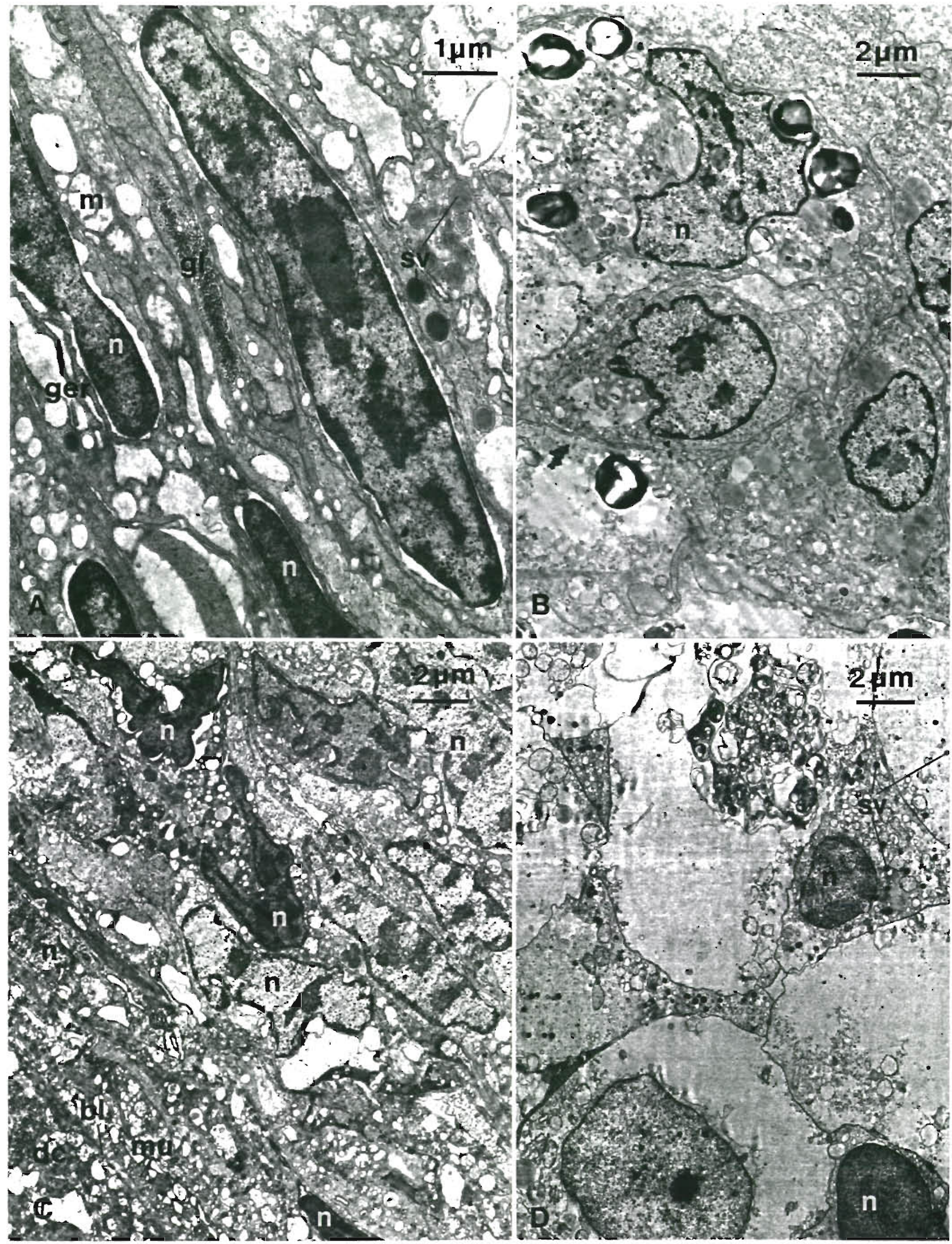

Fig. 6. Buccinum undatum parasitized by Zoogonordes viviparus. (A) TEM mucrograph showing flattened haemocytes in the periphery of the capsule shown in Fig. 5C. (B) Cells containing residual bodies from the center of the capsule. (C) The periphery of the granuloma formation shown in Fig. 5D (D) Rounded cells from the center of the granuloma formation 


\section{DISCUSSION}

The present light microscopical observations of the interaction between sporocysts and snail tissue generally agree with similar studies of sporocysts in natural or susceptible hosts (e.g. Pan 1965). Electron microscope studies of the relation between sporocysts and snail cells are rare.

The general morphology of the body wall of the daughter sporocyst of Zoogonoides viviparus does not differ essentially from that of most daughter sporocysts or rediae described at the ultrastructural level (Koie 1971a, b, Reader 1972, Hoskin 1975). However, some daughter sporocysts have been described as possessing an external nucleated layer outside the tegument. This external layer is often mentioned as the 'paletot'. Such 2-layered sporocysts have been described at the ultrastructural level (James et al. 1966, James \& Bowers 1967, Popiel 1978, Popiel \& James 1978a, b). However, the electron micrographs clearly show that the outer nucleated layer is of host origin. It must be emphasized that a nucleated cell layer of parasite origin never occurs outside the syncytial tegument of any daughter sporocyst or redia when these occur in the molluscan tissue. The cell layer ('primitive epithelium') which surrounds developing daughter sporocysts disappears before these leave the mother sporocyst (Meuleman et al. 1980).

Host reactions resulting in the formation of fewlayered or loosely packed host capsule around daughter sporocysts in susceptible hosts have been described at the ultrastructural level by Yoshino (1976) and Krupa et al. (1977). These host responses may, similarly to the 'paletot' and the layers of flattened haemocytes around the sporocysts of Zoogonoides viviparus, be regarded as an attempt by the host to wall off the parasite.

The tegument of the sporocyst is the sole organ for uptake of nutrients. Absorption by the external surface of sporocysts may be enhanced by the presence of various structural modifications such as microvilli, folds, ridges and invaginations (Matricon-Gondran 1969, Køie 1971b, Žđárská \& Soboleva 1982) which amplify the surface area of the tegument. The extensive amplification in surface area of trematodes may be correlated with their capacity to actively transport, among other things, glucose (Uglem \& Lee 1985).

The external surface area of the sporocyst of Zoogonoides viviparus is less increased than that of Cercaria buccini which has long thin microvilli (Køie 1971b). The different surface topography of the 2 sporocyst species, which both use Buccinum undatum as first intermediate host, may reveal the different demand of nutrients by these species. The 2 sporocyst species have a different effect on the snail tissue. The sporocysts of $Z$. viviparus have no digestive effect on the snail cells, whereas the sporocysts of $C$. buccini destroy the host connective tissue and most digestive gland tubules. The 2 sporocyst species feed on different parts of the snail host. The sporocysts of $C$. buccini may absorb decomposed snail cells, whereas those of $Z$. viviparus must feed on intercellular fluid (haemolymph) and disintegrated extracellular material only.

A defence mechanism involving the encapsulation of parasites or other foreign bodies by molluscan cells has often been described (e.g. Sminia et al. 1974, Harris 1975, Lie et al. 1980, 1981, Jeong et al. 1984). Sminia et al. (1983) stated that distinct morphologically different types of haemocytes, without transitional stages, do not occur in gastropods, and that the different developmental states vary in functional capabilities, e.g. encapsulation, tissue repair and synthesis of humeral factors. The haemocytes involved in phagocytosis and encapsulation of foreign material or in wound healing still have the capacity to divide (Sminia 1974).

The encapsulation reaction around sporocysts of Zoogonoides viviparus is comparable with the defence reaction against parasites in resistant snails or against irradiated parasites in susceptible snails (Lie et al. 1980, Jeong et al. 1984). Buccinum undatum is a susceptible host and is the only known first intermediate host for $Z$. viviparus in Danish waters. Susceptible molluscan hosts normally do not show a pronounced cellular reaction against their compatible trematode parasites. The host reaction resulting in the formation of a capsule around sporocysts of $Z$. viviparus may be associated with the removing of dead or moribund parasites. As mature sporocysts occur first in the gonadal region, and as most encapsulated sporocysts were found here, it is likely that the sporocysts which are attacked by the phagocytizing haemocytes are senescent.

\section{LITERATURE CITED}

Harris, K. R. (1975). The fine structure of encapsulation in Biomphalaria glabrata. Ann. N. Y. Acad. Sci. 266: 446-464

Hoskin, G. P. (1975). Light and electron microscopy of the host-parasite interface and histopathology of Nassarius obsoletus infected with rediae of Himasthla quissetensis. Ann. N. Y Acad. Sci. 266: 497-512

James, B. L., Bowers, E. A., Richards, J. G. (1966). The ultrastructure of the daughter sporocyst of Cercaria bucephalopsis haimaena Lacaze-Duthiers, 1854 (Digenea: Bucephalidae) from the edible cockle, Cardium edule L. Parasitology 56: 753-762

James, B. L., Bowers, E. A. (1967). Reproduction in the daughter sporocyst of Cercaria bucephalopsis haimeana (Lacaze-Duthiers, 1854) (Bucephalidae) and Cercaria dichotoma Lebour, 1911 (non Müller) (Gymnophallidae). Parasitology 57: 607-625 
Jeong, K. H., Lie, K. J., Heyneman, D. (1984). An ultrastructural study on ventricular encapsulation reactions in Biomphalaria glabrata exposed to irradiated echinostome parasites. Int. J. Parasit. 14: 127-133

Koie, M. (1971a). On the histochemistry and ultrastructure of the redia of Neophasis lageniformis (Lebour, 1910) (Trematoda, Acanthocolpidae). Ophelia 9: 113-143

Koie, M. (1971b). On the histochemistry and ultrastructure of the daughter sporocyst of Cercaria buccini Lebour, 1911 Ophelia 9: 145-163

Køie, M. (1971c). On the histochemistry and ultrastructure of the tegument and associated structures of the cercaria of Zoogonoides viviparus in the first intermediate host. Ophelia 9: 165-206

Koie, M. (1976). On the morphology and life-history of Zoogonoides viviparus (Olsson, 1868) Odhner, 1902 (Trematoda, Zoogonidae). Ophelia 15: 1-14

Krupa, P. L., Lewis, L. M., Vecchio, P. D. (1977). Schistosoma haematobium in Bulinus guernei: electron microscopy of hemocyte-sporocyst interactions. J. Invertebr Pathol. 30: $35-45$

Lie, K. J., Jeong, K. H., Heyneman, D. (1980). Tissue reactions induced by Schistosoma mansoni in Biomphalaria glabrata. Ann. trop. Med. Parasit. 74: 157-166

Lie, K. J., Jeong, K. H., Heyneman, D. (1981). Selective interference with granulocyte function induced by Echinostoma paraensei (Trematoda) larvae in Biomphalaria glabrata (Mollusca). J. Parasit. 67: 790-796

Matricon-Gondran, M. (1969). Étude ultrastructurale du syncytium tégumentaire et de son évolution chez des trématodes digénétiques larvaires. C. $r$. hebd. Séanc. Acad. Sci., Paris (Sér. D) 269: 2384-2387

Meuleman, E. A., Holzmann, P. J., Peet, R. C. (1980). The development of daughter sporocysts inside the mother sporocyst of Schistosoma mansoni with special reference to the ultrastructure of the body wall. $\mathbf{Z}$. ParasitKde 61 : 201-212

Pan, C. T (1965). Studies on the host-parasite relationship between Schistosoma mansoni and the snail Australorbis glabratus. Am. J. trop. Med. Hyg. 14: 931-976

Popiel, I. (1978). The ultrastructure of the daughter sporocyst of Cercaria littorinae saxatilis V Popiel, 1976 (Digenea: Microphallidae). Z. ParasitKde 56: 167-173

Popiel, I., James, B. L. (1978a). Variations in the ultrastructure of the daughter sporocyst of Microphallus pygmaeus (Levinsen, 1881) (Digenea: Microphallidae) in chemically defined media. Parasitology 76: 349-358

Popiel, I., James, B. L. $(1978 \mathrm{~b})$. The ultrastructure of the tegument of the daughter sporocyst of Microphallus similis (Jäg., 1900) (Digenea: Microphallidae). Parasitology 76: 359-367

Reader, T. A. J. (1972). Ultrastructural and cytochemical observations on the body wall of the redia of Sphaeridiotrema globulus (Rudolphi, 1819). Parasitology 65: $537-546$

Sminia, T. (1974). Haematopoiesis in the freshwater snail Lymnaea stagnalis studied by electron microscopy and autoradiography. Cell Tiss. Res. 150: 443-454

Sminia, T., Borghart-Reinders, E., van de Linde, A. W. (1974). Encapsulation of foreign materials experimentally introduced into the freshwater snail Lymnaea stagnalis. Cell Tiss. Res. 153: 307-326

Sminia, T., Van der Knaap, W. P. W., Van Asselt, L. A. (1983). Blood cell types and blood cell formation in gastropod molluscs. Dev. Comp. Immunol. 7: 665-668

Uglem, G. L., Lee, K. J. (1985). Proterometra macrostoma (Trematoda: Azygiidae): functional morphology of the tegument of the redia. Int. J. Parasit. 15: 61-64

Yoshino, T P. (1976). Encapsulation response to the marine prosobranch Cerithidea californica to natural infections of Renicola buchanani sporocysts (Trematoda: Renicolidae) Int. J. Parasit. 6: 423-431

Ždárská, Z., Soboleva, T N. (1982). Ultrastructure of the tegument of Hasstilesia ovis larval stages. Folia Parasit. 29: $367-370$ 